\title{
Spirit of Tolerance (Kanyou) in the Novel Utsukushisa To Kanashimi To by Kawabata Yasunari: the Study of Cultural Stylistics
}

\author{
Ina Ika Pratita \\ Japanese Language and Literature Department \\ Universitas Negeri Surabaya \\ Surabaya, Indonesia \\ inapratita@unesa.ac.id
}

\begin{abstract}
This research was conducted to explore the cultural values that grow and develop and dominate the Japan Society, a way of thinking that is contained in the spirit of tolerance (Kanyou). The main character is a woman, named Otoko, whose played a role to depict a cultural stylistics in the community. This research aims to describe cultural values with the spirit of tolerance (Kanyou) contained in the novel Utsukushisa To Kanashimi To by a Japanese author, Kawabata Yasunari with Stylistics Cultural studies. The approach of cultural stylistics, meanings can be excavated in full compliance with the community's cultural-philosophical meaning Japan. The object of this research is the cultural values found in the novel of Utsukushisa To Kanashimi To and conformity as literary learning materials. Data collection methods used in this research is a method of documentation. The data was analysed using descriptive qualitative techniques. The results of this research are that the cultural values that grow and develop and dominate the Japan Society is contained in the spirit of tolerance (Kanyou). They are the value of responsibility, the value of appreciating, the value of respect, and the value of honesty. Based on the results of this study, other researchers are advised to examine more deeply about human values found in the literature, particularly novel. Keywords-component: cultural values, stylistics, cultural stylistics, Spirit of Tolerance, Kawabata Yasunari
\end{abstract}

\section{INTRODUCTION}

Passion for tolerance is one characteristics that stand out in the way of thinking of Japanese people. Indeed, the spirit of tolerance is based on the tightness of the social control and the strong pressure to an individual Japanese people in the life of society. Thus, in terms of the subjective awareness of a Japanese, the spirit of tolerance is obviously seen. The dominant idea in this novel boils down to a representation of the Spirit of Tolerance (Kanyou), the representation is meant to refer to the creation of meaning. The subject of the representation is the meaning that emerged from a condition. The content of their meaning has a relation of meaning with cultural values and norms of Japanese society in a functional relationship with the natural environment and the social function of culture. It becomes one's guideline in the living society. Then, how the meaning is applied in the society that is explored in the novel of Utsukushisa To Kanashimi To to bring up the values that dominate the way of thinking of Japanese people. Precisely, the novel tells the representation of the thinking of the Japanese people, in particular to explore the behavior and motivation of the character in the literary works which directly or indirectly describe the behavior and motivation of the author, namely Kawabata.

A value is the set of references used as a basis for judgment, standards or principles that become the size of the (truth, goodness, beauty) of the copyright, the work, the intention and human behavior in general. So value is something precious, top quality, show quality, and useful for humans. Something that value means something is valuable or useful for human life.

The spirit of Tolerance (Kanyou), that each other supports the values, dominates the way of thinking of Japanese people. The properties and characteristics of nature has been metaphors to the nature and human behavior. This is the embodiment of the philosophy of nature that can be used as a guide to life. This has opened various cracks to be studied, especially with regard to cultural values.

This study aims to describe (1) cultural values with a Spirit of tolerance (Kanyou) contained in the novel Utsukushisa To Kanashimi To by Kawabata Yasunari based on Cultural stylistics approach and (2) the suitability of the novel Utsukushisa To Kanashimi To as learning materials literature. The approach of stylistics cultural meanings can be explored in full in accordance with the meaning of the philosophicalcultural Japanese society. The object of this research is the cultural values contained in the novel Utsukushisa To Kanashimi To and suitability as learning materials literature.

\section{LITERATURE REVIEW}

\section{A. Language and Culture}

Language is the main instrument of human to integrate itself both internally and externally as individuals who serve and active participants in a group or human society (Mc Quown, 1978), In the context of culture, language not only can be viewed as a means of communication of the individual or group to express thoughts, feelings, opinions, hope, anxiety, love, hate, opinions, and so on to other individuals or groups, but can also be viewed as a resource to unveil the mysteries of 
culture, ranging from the behavior of language, identity and the life of the speakers, the utilization and empowerment of language to the development and preservation of cultural values. Departing from this paradigm, then the study of language is not only limited to the study of micro that is done solely for the sake of the language itself and at the same time could be viewed as the argumentation to consider linguistics as a science culture.

\section{B. Cultural Stylistics}

Stylistics is a discipline of science that examines the function of the artistic use of language in various contexts. Stylistics give an explanation regarding the accuracy and inaccuracy of the use of various elements of language in a text. Stylistics are in the point of intersection of the study of linguistics, literature, and culture. Cultural stylistics is an approach used in the study of the style of a text that is laden with philosophical meaningcultural. Understanding the style of the text will be the best if done right with the depart and or consider the cultural aspects that shape. Text of literature which raised the cultural aspect of the community, it seems more appropriate if approached, analyzed, or understood by the approach stylistics cultural. One of the aspects that need to be considered in the context is culture. The context of the cultural is not uncommon dye form style. This state indicates that the style usually affected and influenced by the conditions of culture of the people.

In the context of cultural, language not only can be viewed as a means of communication of the individual or group to express thoughts, feelings, opinions, hope, anxiety, love, hate, opinions, and so on to other individuals or groups, but can also be viewed as a resource to unveil the mysteries of culture, ranging from the behavior of language, identity and the life of the speakers, the utilization and empowerment of language to the development and preservation of cultural values. It shows that in a discourse, the texts of the literary style used may simultaneously contain elements of culture. As a consequence study on stylistics against a form of language used should also consider the cultural aspect. In short, stylistics can also be studied by a cultural approach (Zyngier, 2001). In the context of stylistics all of which confirms the existence of a close connection between the study of linguistics and the study of literature and culture, stylistics be comfortable between the two Stylistics to be in the middle between the poles of the linguistic on the one hand and the poles of art and culture on the other side. Zyngier (2001) describes the relationship of these three disciplines as shown in the image below.

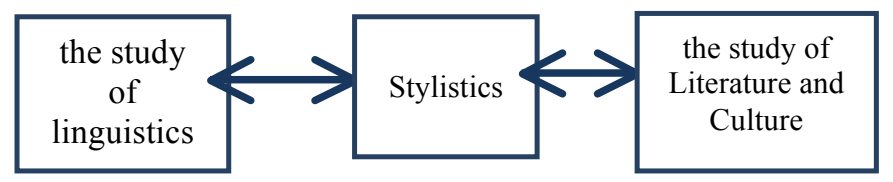

With this approach meaning can be explored in full in accordance with the meaning of the philosophical-cultural society bearers of that culture. If culture is regarded as the construct of mental that allows it to survive and at the same time as a way of life, construct it concretely manifests itself primarily through language. Not strange if the language, the style used by community members of a particular community reflects their culture.

C. Cultural values in the Novel Utsukushisa To Kanashimi To with the Spirit of Tolerance (Kanyou)

Value is something that concerns the good and bad. Pepper (in Djajasudarma, 1997) states that the limit of value refers to the interests, preferences, choices, duty, obligation, religion, needs, security, desire, lazyness, attractions, feelings, and orientation selection. Therefore, everything that good and bad can be referred to as the value. The system of values, including cultural values, is a guideline adopted by every member of the community, especially in act and behave and also become the benchmark to assess and scrutinize how individuals and groups act and behave. So, a value system can be regarded as the standard norm in the life of society. Djajasudarma (1997) argues that the value system is so strong, pervasive, and deeply rooted in the society soul so it is difficult to be replaced and/or changed in a short time. The language of manifest classification system can be used to explore cultural practices in a society. Models of culture can be raised explicitly through the expression (Bonvillain, 2011). Models of culture that are meant here include the spirit of Tolerance (Kanyou) that supports the values that dominate the way of thinking of Japanese people, namely, which will be described in detail successively as follows: the Value of Responsibility, the Value of the Appreciate, the Value of Respect, and the Value of Honesty.

\section{METHOD}

Through a survey, data that contains the value of cultural is collected. Steps for the research are as follows: (i) data collection; (ii) data identification: data that contains the value of cultural; (iii) data classification; (iv) data transcription; and (v) data interpretation.

Subject: Novel; Objects: the cultural values found in the novel Utsukushisa To Kanashimi To and conformity as literary learning materials. Data collection instrument (documentation, observation). The data was analysed using descriptive qualitative techniques; (i) description of findings, (ii) description of conclusions. The approach of stylistics cultural meanings can be explored in full in accordance with the meaning of the philosophical-cultural Japanese society.

\section{DISCUSSION}

Tolerance comes from the Latin; tolerare, means to hold back, be patient, let the people argue the other, and take field against people who have different opinions. The tolerant attitude does not mean to justify the view that left it, but recognize the freedom and rights of its adherents. Tolerance of such properties or the attitude of tolerate (appreciate, let, allow) means the establishment of (an opinion, view, belief, habits, behavior and so on) that are different or in conflict with the establishment of its own (Great Dictionary of English Edition. 2 Mold 4 Th.1995). Pratita (2012) argues that consecutively, the spirit of tolerance (Kanyou) are (1) the Value of Responsibility, (2) the Value of Appreciation, (3) the Value of 
Respect, and (4) the Value of Honesty. The value of responsibillity will be described below for an example:

\section{The Value of Responsibility}

As civilized beings, someone should learn to solve their own problems without blaming others. When everyone is trying to fix itself, there will be no problems in this world. But many people do not seek to realize, that they alone are responsible for many troubles that experienced by themselves. They prefer to find scapegoats. They think, that all sources of distress do not cause by them, because they are reluctant to admit their weaknesses. The human mind is full of fraud on themselves, such that they do not want to admit his own weakness, and looking for reasons to justify their actions and create the illusion that they are not guilty. If somebody really want to be free from his or her illution, he or she must have the courage to admit his or her own weaknesses. A person must learn to be responsible for his or her life and acknowledge the weakness of yhimself or herself, without blaming or disturbing others.

In the novel Utsukushisa To Kanashimi To, the value of responsibility is depicted in the figure of Otoko. Otoko is a woman who is very family-oriented. Note the following quote below.

Data1 (R-01 ST)

Context: Conversation Otoko with Keiko, when you say that women should get married and have children

「女には、結婚ということも、子どもということもある し。」(Kawabata, 2005:123)

Onna ni wa, kekkon to iu koto mo, kodomo to iu koto mo aru shi.

"A woman, should get married and have children".

Figure Otoko in the novel Utsukushisa To Kanashimi To is a woman who crave a family, she also still keeps her love to Oki and his baby. In a conversation Otoko realize that her relationship with Keiko, her fellow woman, will not last long, because Otoko had the thought that a woman should get married and have children. The decision Otoko to not get married is because she is keeping her love to Oki, though she felt guilty to her mother over the decision.

Figure Otoko does not consider that a family is a suffering for her, although in fact she suffered by a man. She still considers a family is an important thing for a woman. So it can be concluded that in figures of Ueno Otoko in the novel Utsukushisa To Kanashimi To, she was responsible for the behavior or actions that she has done intentionaly or not on purpose. She should learn to keep her thoughts for many years to maintain the correct value, that a family is an important thing for a woman. She did not blame the condition of the wrong doing. She did not circumvent her own responsibility for all her actions by blaming the condition. Whatever happens, Otoko will not feel it as suffering as long as she knows how to keep the balance of her mind.

\section{CONCLUSION}

The uniqueness of Kawabata to face revenge and evil in the novel Utsukushisa To Kanashimi To each other supports the cultural values that grow and evolve to dominate the way of thinking of Japanese people, that is contained in: a Spirit of Tolerance (Kanyou): the value of responsibility. It is depicted in figure of Otoko, a woman who is very familyoriented, value appreciated, illustrated in the figure of Otoko. Her love to Oki is so great. For her, nothing can change her love to Oki, including her woman lover-Keiko. The value of respect, shown in the attitude of Keiko who is a firm woman and assume that Otoko is a stupid woman since she loves a man whose gives her suffer. The value of honesty is shown by the attitude of Keiko who said honesty to Otoko that she will get revenge on Oki for Otoko.

Knowledge about the cultural values will make a person survive in the life of society, adapt, and build social integration. Cultural values will be a good guideline in living in a society. Therefore, there is a need to examine more deeply about the human values contained in literary works, especially novels.

\section{REFERENCES}

[1] Mc Quown, Norman A. Linguistics and Anthropology in Archibald A Hill (ed) Linguistics. USA: Voice of America Forum Series. 1978

[2] Sonia Zyngier. Towards a Cultural Approach to Stylistics. Online http-cvc.cervantes.esliteratureacaucepdf-cauce24, 2001

[3] T.Fatimah Djajasudarma. Nilai Budaya dalam Ungkapan dan Peri-bahasa Sunda. Jakarta: Pusat Pembinaan dan Pengembangan Bahasa, Departemen Pendidikan dan Kebudayaan, 1997.

[4]Nancy Bonvillain, Language, Culture and Communication: The Meaning of Messages. USA: Pearson Education. 2011

[5]Depdikbud.. Kamus Besar Bahasa Indonesia, Jakarta : Balai Pustaka, 1995

[6] Pratita, Ina Ika. 2012. Stilistika Novel Utsukushisa To Kanashimi To 「美しさ哀しみと」Karya Kawabata Yasunari.Disertasi. Program Pascasarjana. Universitas Negeri Malang. 